Vera Vidaković, Milena Stefanović, Miroslav Novaković, Milka Jadranin, Zorica Popović, Rada Matić, Vele Tešević and Srdjan Bojović*

\title{
Inter- and intraspecific variability of selected diarylheptanoid compounds and leaf morphometric traits in Alnus glutinosa and Alnus incana
}

https://doi.org/10.1515/hf-2018-0019

Received January 26, 2018; accepted June 27, 2018; previously published online $x x$

Abstract: The reliability of diarylheptanoids as chemotaxonomic markers at inter- and intraspecific levels has been investigated. Six diarylheptanoids were quantified in bark ethanol extracts of four Alnus spp. populations by ultra-performance liquid chromatography-tandem mass spectrometry (UPLC-MS/MS). The populations described here as locus classicus Alnus glutinosa (I) and locus classicus Alnus incana (III) are clearly differentiated. Compared to population I, individuals in population III have higher extract yields and hirsutanonol-5-O- $\beta$-D-glucopyranoside content and lower contents of hirsutanonol, rubranoside $\mathrm{A}$ and oregonin. Individuals from neighboring populations of A. glutinosa (II) and A. incana (IV) share similar contents of hirsutanonol. All the studied populations exhibit a high intrapopulation variability of the selected diarylheptanoids; they have a heterogeneous chemotype and they partially overlap. The geographical proximity of populations II and IV increases their chemical similarity. Principal component analysis (PCA) clearly shows that the biggest dispersion of individuals lies within population IV. The reason for its heterogeneity might be its physical proximity to population II, i.e. the appearance of hybrids. Also, geometric morphometrics of leaves was performed as a screening criterion for spontaneous hybrids.

\footnotetext{
*Corresponding author: Srdjan Bojović, Institute for Biological Research "Siniša Stanković”, University of Belgrade, Bulevar despota Stefana 142, Belgrade 11060, Serbia, e-mail: bojovic@ibiss.bg.ac.rs Vera Vidaković, Milena Stefanović, Zorica Popović and Rada Matić: Institute for Biological Research "Siniša Stanković”, University of Belgrade, Bulevar despota Stefana 142, Belgrade 11060, Serbia. http://orcid.org/0000-0003-2330-208X (V. Vidaković) Miroslav Novaković and Milka Jadranin: Center for Chemistry Institute of Chemistry, Technology and Metallurgy, University of Belgrade, Studentski trg 12-16, Belgrade 11000, Serbia Vele Tešević: Faculty of Chemistry, University of Belgrade, Studentski trg 12-16, Belgrade 11000, Serbia
}

Keywords: Alnus glutinosa, Alnus incana, Betulaceae, diarylheptanoid, geometric morphometrics, hirsutanonol-5$O-\beta$-D-glucopyranoside, oregonin, principal component analysis (PCA), rubranoside A

\section{Introduction}

Alnus glutinosa (L.) Gaertn. (black alder) and Alnus incana (L.) Moench (gray alder) are plant species in the family Betulaceae. Alnus species are probably the most important vascular plants in European forests that fix atmospheric nitrogen (Mikola et al. 1983). They act as water and air filters, protect riparian systems from excessive erosion and contribute to biodiversity by providing habitats for specific flora and fauna both on their aboveground parts and in the flooded root system (Mejnartowicz 2008; Claessens et al. 2010). Black alder is distributed all over Europe, from central Scandinavia in the north to the Mediterranean in the south, and from Ireland in the west to Siberia in the east. It is most often found in damp sites near springs, creeks and rivers and on mountains 600-1000 m a.s.l. Gray alder is found mainly in northern, middle and southeastern Europe in moist sites at altitudes up to $2000 \mathrm{~m}$ (Jovanović 2007). Hybrids between black and gray alder are commonly found within sympatric populations of the two species (Banaev and Bažant 2007; Bašić et al. 2014). The morphological characteristics of species and hybrids have been extensively studied and are well described (Parnell 1994; Banaev and Bažant 2007; Vander Mijnsbrugge 2015).

Woody species like alder that have large geographic ranges, outcrossing breeding systems, widely dispersed seeds and both generative and vegetative reproductive strategies commonly exhibit greater genetic diversity within species and populations and less variation between populations (Hamrick et al. 1992; Mejnartowicz 2008). Chemodiversity is the variation of the composition of secondary metabolites among species, populations, individuals and different plant parts (e.g. Moore et al. 2014). In chemotaxonomic studies of plants, different methods are used [e.g. chemiresistor sensor array (Kalaw and Sevilla III 2018), Fourier-transform infrared (FTIR) absorption (Wang et al. 2016), DNA analysis (Yu et al. 2016)] as well as 
various chemical compounds, of which secondary metabolites are considered good chemotaxonomic markers (Nawawi et al. 2016; Sartori et al. 2016; Wu et al. 2017). Chemotaxonomy is helpful in plant taxonomy on different hierarchical levels. For example, Šarac et al. (2013) differentiated infraspecific taxa of Pinus nigra J.F. Arnold on the basis of essential oil composition; Wu et al. (2017) showed that two morphologically very similar species, Cinnamomum micranthum Hayata and Cinnamomum kanehirae Hayata, the latter being endemic to Taiwan, can be distinguished by the chemical profiles of their leaf methanol extracts, and Anderson et al. (1970) revealed different resin acid distributions in several subgenera of Pinus. It is well documented that the qualitative and quantitative chemical composition in a plant depends on both genotype and environmental conditions. Therefore, secondary metabolism variability at the population level will reflect population diversity, which is an important adaptive plant response to fluctuations in environmental conditions. Moreover, quantitative variability in chemical traits has been shown to differentiate hybrid individuals from parent species (van Rozendaal et al. 1999; Orians et al. 2000; Banjanac et al. 2017).

Leaf habit plays a crucial role in the systematics of the genus Alnus Mill. s.l. (Banaev and Bažant 2007). The leaf morphology of Alnus spp. has been thoroughly studied based on traditional morphometrics (Banaev and Bažant 2007; Banaev 2009; Akbarian et al. 2011; Krauze-Michalska and Boratyńska 2013), where each individual measurement is regarded as a trait in its own right and is recognized as a single variable. It is common to draw biological conclusions based on separate analyses of single measurements. On the other hand, in geometric morphometrics, the shape of an individual is described with a configuration of landmarks, which represents a multidimensional datum rather than a collection of multiple variables (Zelditch et al. 2012). Analyses of configurations are necessarily multivariate and have a greater ability to detect subtle differences in morphology. Recently, Vander Mijnsbrugge (2015) described geometric morphometrics to examine the phenotypic variability of black and gray alder and their putative hybrids.

Diarylheptanoids are a group of natural products extensively investigated for a variety of bioactivities. They have been reported to exhibit anti-inflammatory, antioxidant, cytotoxic, estrogenic, antimicrobial, antiparasitic, hepatoprotective, neuroprotective and many other activities (Dinić et al. 2014; Novaković et al. 2014, 2015; Huang et al. 2016; Saxena et al. 2016; Sueth-Santiago et al. 2016; Suksen et al. 2016; Thongon et al. 2017). In our previous work, it was demonstrated that diarylheptanoids are powerful indicators in the identification of and discrimination between the species A. glutinosa and A. incana (Vidaković et al. 2018).

The purpose of the present study was to check the reliability of diarylheptanoids as chemotaxonomic markers at the inter- and intraspecific levels by examining the following: (1) variability of populations described as locus classicus A. glutinosa and locus classicus A. incana; (2) variability of geographically closely located populations of A. glutinosa and A. incana; and (3) variability and relations of populations within and among species. In addition, landmark-based geometric morphometrics of leaves will be carried out to investigate the appearance of hybrids.

\section{Materials and methods}

Chemicals: Diarylheptanoids used as standards (hirsutanonol-5-O$\beta$-D-glucopyranoside, oregonin, hirsutanonol, alnuside A, platyphylloside and rubranoside A) (Figure 3) were isolated from the bark of A. glutinosa (Novaković et al. 2013). The extraction solution (96\% EtOH,

Table 1: Geographic location of the studied populations (I, II, III and IV) and sample size ( $n_{t}$ - number of trees, $n_{l}-$ number of leaves).

\begin{tabular}{|c|c|c|c|c|}
\hline \multirow[b]{2}{*}{ Species } & \multicolumn{2}{|l|}{ A. glutionosa } & \multicolumn{2}{|l|}{ A. incana } \\
\hline & I & II & III & IV \\
\hline Locality & Prilički kiseljak & Rimski most & Golijska reka & Sastavci \\
\hline Latitude (N) & $43^{\circ} 36^{\prime} 55^{\prime \prime}$ & $43^{\circ} 28^{\prime} 09.2^{\prime \prime}$ & $43^{\circ} 21^{\prime} 46^{\prime \prime}$ & $43^{\circ} 27^{\prime} 38.5^{\prime \prime}$ \\
\hline Longitude (E) & $20^{\circ} 08^{\prime} 04^{\prime \prime}$ & $20^{\circ} 14^{\prime} 05.9^{\prime \prime}$ & $20^{\circ} 15^{\prime} 26^{\prime \prime}$ & $20^{\circ} 13^{\prime} 22.0^{\prime \prime}$ \\
\hline Altitude (m) & 565 & 655 & 1396 & 670 \\
\hline Forest community & $\begin{array}{l}\text { Querco-Carpinetum } \\
\text { sensu lato }\end{array}$ & $\begin{array}{l}\text { Querco-Carpinetum } \\
\text { sensu lato }\end{array}$ & $\begin{array}{l}\text { Piceo-Alnetum } \\
\text { incanae }^{\mathrm{a}}\end{array}$ & $\begin{array}{l}\text { Fagetum montanum } \\
\text { sensu lato }\end{array}$ \\
\hline Bark samples & & & & \\
\hline $\begin{array}{l}n_{t} \\
\text { Leaf samples }\end{array}$ & 21 & 20 & 21 & 18 \\
\hline$n_{t}$ & 21 & 20 & 21 & 21 \\
\hline$n_{l}$ & 397 & 350 & 365 & 346 \\
\hline
\end{tabular}

${ }^{\mathrm{a} G a j i c ́}$ (1989). 
Reahem, Novi Sad, Serbia) was freshly distilled. Solvents for ultra-performance liquid chromatography-tandem mass spectrometry (UPLCMS/MS) analysis were of chromatographic grade (Sigma-Aldrich, St. Louis, MO, USA).

Plant material: Qualitative and quantitative secondary metabolite variation in a species is influenced by several factors, such as plant age and size, tissue type, ontogenic stage, circadian and annual cycles (Moore et al. 2014). To reduce uncontrolled influences on the diarylheptanoid content, sample uniformity was looked for by selecting mature trees of similar age and by sampling the bark within a few

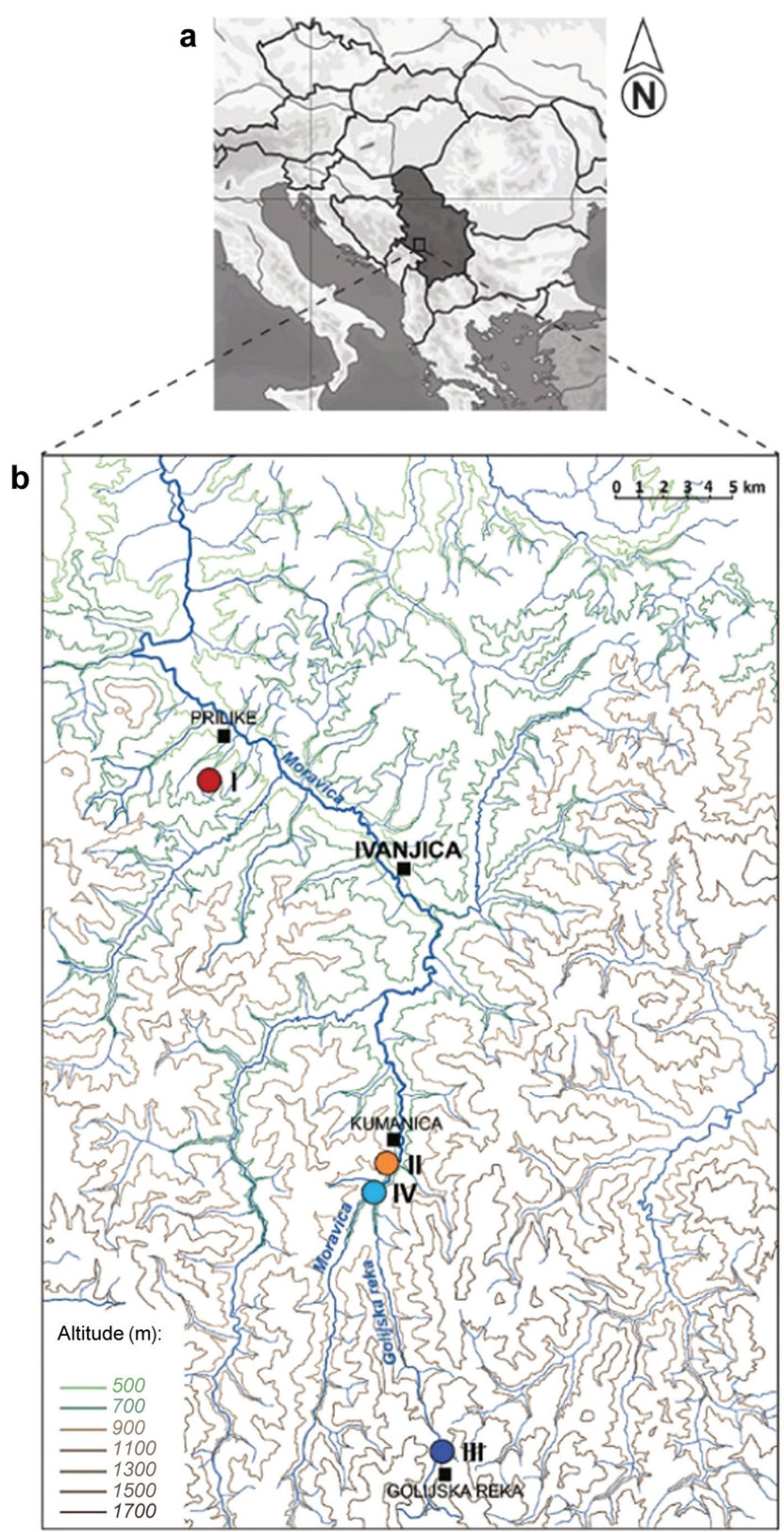

Figure 1: Locations of the studied populations.

(a) Map of the Balkan Peninsula (Serbia is shaded), with the study area in the rectangle. (b) The Moravica River basin with $A$. glutinosa (I and II) and $A$. incana (III and IV) populations marked. days in the same season (22-23 April 2016), from the same tree height and exposition. Four natural populations of A. glutinosa (I and II) and A. incana (III and IV) were sampled in the Golija-Studenica Biosphere Reserve (UNESCO-MAB) (II-IV) and on the northern border of Mt. Golija (I) (Table 1, Figure 1). Taxonomic identification of the plant material was done by Dr. Srdjan Bojović. The voucher specimens are deposited in the Herbarium of the Department of Ecology in the Institute for Biological Research, University of Belgrade, Serbia. The bark from 80 Alnus spp. trees was collected. The bark was air-dried and milled into powder. In addition, leaves from 83 trees were sampled in October 2017 for morphometric analysis.

Two relatively distant populations (30 km apart), locus classicus A. glutinosa (I) and locus classicus A. incana (III), were selected as control trees. Two relatively close populations (1.2 km apart), A. glutinosa (II) and A. incana (IV), were selected to examine the chemovariability, i.e. the presence of interspecific hybridization.

Preparation of bark extracts: Powdered bark samples (2 g) were extracted with $96 \%$ EtOH $(20 \mathrm{ml})$ four times during $24 \mathrm{~h}$ assisted by an ultrasonic bath in the last hour of each extraction. Extract solutions were evaporated. The extractives were dissolved in $\mathrm{MeOH}$ to a final concentration of $0.2 \mathrm{mg} \mathrm{ml}^{-1}$ and filtered through a $0.45-\mu \mathrm{m}$ poresize filter (Agilent Technologies, Waldbronn, Baden-Württemberg, Germany) prior to ultraperformance liquid chromatographyelectrospray ionization-tandem mass spectrometry (UPLC-ESI-MS/ MS) analyses.

UPLC triple quad MS-MS analysis: Standard solutions for calibration were prepared from $500 \mu \mathrm{g} \mathrm{ml}^{-1}$ stock solution of a mixture of diarylheptanoid standards (hirsutanonol-5-O- $\beta$-D-glucopyranoside, oregonin, hirsutanonol, alnuside A, platyphylloside and rubranoside A) in $\mathrm{MeOH}$. The concentrations of the calibration solutions ranged from $2.510^{-3}$ to $200 \mu \mathrm{g} \mathrm{ml}^{-1}$.

UPLC-ESI-MS/MS analyses were performed using a Waters Acquity Ultra Performance H Class system (Waters, Milford, MA, USA). Samples were separated on a Zorbax Eclipse Plus C18 column $(1.8 \mu \mathrm{m}, 2.1 \mathrm{~mm} \times 100 \mathrm{~mm}$ ) from Agilent technologies (Waldbronn, Baden-Württemberg, Germany) that was maintained at $40^{\circ} \mathrm{C}$. The mobile phase consisted of $0.2 \%$ formic acid in water (solvent $\mathrm{A}$ ) and acetonitrile (solvent $\mathrm{B}$ ). The gradient elution program at a flow rate of $0.4 \mathrm{ml} \mathrm{min}{ }^{-1}$ was as follows: $0.0-6.0 \mathrm{~min} 19 \% \mathrm{~B}$; 6.0-7.0 min 19-21\% B; 7.0-7.1 min 21-100\% B; 7.1-10.0 min 100\% B; 10.0-10.1 min 100-19\% B; $10.1-12.0 \mathrm{~min} 19 \% \mathrm{~B}$. The injection volume was $10 \mu \mathrm{l}$. The compounds were detected and quantified by a triple quadrupole mass spectrometer Acquity TQD (Waters) that operated in multiple reaction monitoring (MRM) mode, as described in Vidaković et al. (2018).

Leaf shape analysis: Mature leaves were collected, which were recognized by their position on the shoots. Because the primary axis of the shoots elongates at one pole, structures formed early in development are located at the base of the shoot (juvenile leaves) and structures formed later assume apical positions (mature and intermediate leaves). The transition from a juvenile to an adult phase of vegetative growth usually occurs gradually and may involve rather subtle changes in shoot morphology and physiology. These differences are most obvious in woody species because of their prolonged juvenile and adult phases. Leaf shape is one of the most conspicuous signs of the vegetative phase of the shoot. Juvenile leaves are usually smaller and simpler in structure. Mature leaves grow in the middle part of the shoot and represent the characteristic shape of the species. Intermediate leaves 
a

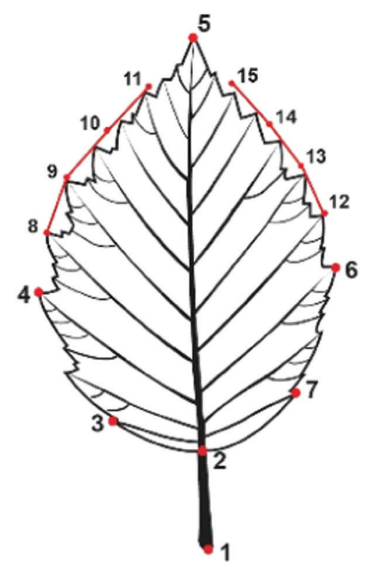

b

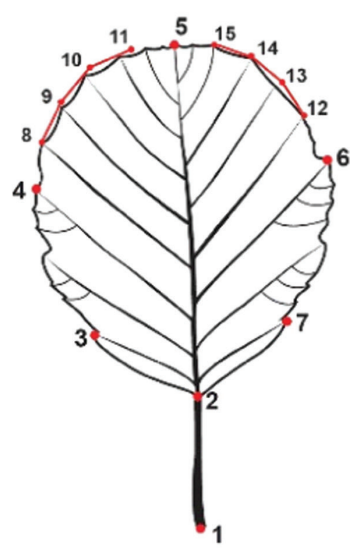

Figure 2: Landmark configurations of $A$. incana (a) and A. glutinosa (b).

Description of landmarks: 1 - beginning of the petiole, 2 - junction of the leaf blade and petiole, 3 and 7 - tips of the first pair of veins starting from the petiole, 4 and 6 - tips of the pair of veins in the widest part of the leaf blade, 5 - apex of the leaf blade, 8-15 - semi-landmarks.

are formed last and take an apical position on the shoots. Depending on the species, they could be characterized by intermediate or more complex shapes (Poethig 1990; Nicotra et al. 2011). Individual leaves were scanned with the abaxial surface up by means of an Epson Perfection V370 scanner (Seiko Epson Corporation, Suwa-shi, Nagano-ken, Japan) at 600 dpi resolution. Basic leaf shapes of both species were described with seven landmarks (Figure 2). Additionally, two curves with four semi-landmarks were drawn on both sides of the leaves to describe the leaf apex. The tips of the veins immediately above landmarks 4 and 6 were used as the starting points of these curves.

Statistical analysis: To compare the populations on the basis of diarylheptanoid contents and yields of bark EtOH extracts, the variables' mean values [analysis of variance (ANOVA)] or medians (Kruskal-Wallis test) were used, depending on the normality of the distribution (Shapiro-Wilk test, $\mathrm{P}>0.05$ indicated normal distribution). Principal component analysis (PCA) was performed for easier comprehension of the structure of the elements and characteristics in extensive tabular data. Skewness of data was corrected by transforming $\left[y^{\prime}=\log _{10}(y+1)\right]$ and standardizing the data. Discriminant analysis (DA) was employed to differentiate a priori defined groups and to assort the elements within the predefined groups. Statistical analyses were carried out using Addinsoft XLSTAT 2017 software (Data Analysis and Statistical Solution for Microsoft Excel, Addinsoft, Paris, France; free trial version) and R statistical software (version 3.4.0: The R Foundation for Statistical Computing, Vienna, Austria, https://www.r-project.org/).

Digitalization of 1458 leaf specimens was carried out by tpsUtil (Rohlf 2016a) and tpsDig (Rohlf 2016b). A full Procrustes fit of coordinates and PCA were performed in MorphoJ (Klingenberg 2011).

\section{Results and discussion}

Qualitative and quantitative secondary metabolite variation in a species is influenced by several factors, such as plant age and size, tissue type, ontogenic stage, circadian and annual cycles (Moore et al. 2014). Vidaković et al. (2018) demonstrated that the concentrations of the diarylheptanoids (i.e. hirsutanonol-5-O- $\beta$-D-glucopyranoside, oregonin, hirsutanonol, alnuside A, platyphylloside and rubranoside A) and their yields in bark EtOH extracts are different in A. glutinosa and A. incana. Chemical structures<smiles>O=C(CCc1ccc(O)c(O)c1)C[C@H](O)COC(O)C(O)C(O)C(O)CO</smiles>

Hirsutanonol-5-O- $\beta$-D-glucopyranoside $\mathrm{Mw}=508.52$<smiles>O=C(CCc1ccc(O)c(O)c1)C[C@@H](O)CCc1ccc(O)c(O)c1</smiles>
Hirsutanonol $\mathrm{Mw}=346.38$<smiles>O=C(CCc1ccc(O)cc1)C[C@H](CCc1ccc(O)cc1)OC(O)C(O)C(O)C(O)C(=O)O</smiles><smiles>O=C(O)CC(O)O[C@@H](CCc1ccc(O)c(O)c1)CC(=O)CCc1ccc(O)c(O)c1</smiles><smiles>O=C(CCc1ccc(O)cc1)C[C@H](O)[C@H](O)CCc1ccc(O)c(O)c1</smiles>

Alnuside A $\mathrm{Mw}=462.49$

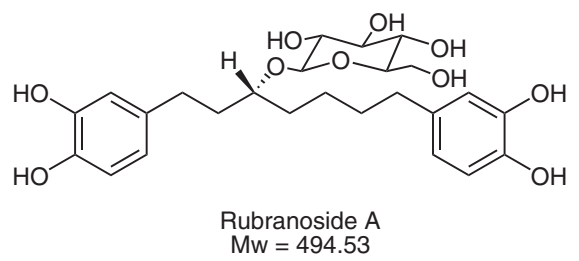

Figure 3: Chemical structures and molecular weights of diarylheptanoid compounds used as standards. 


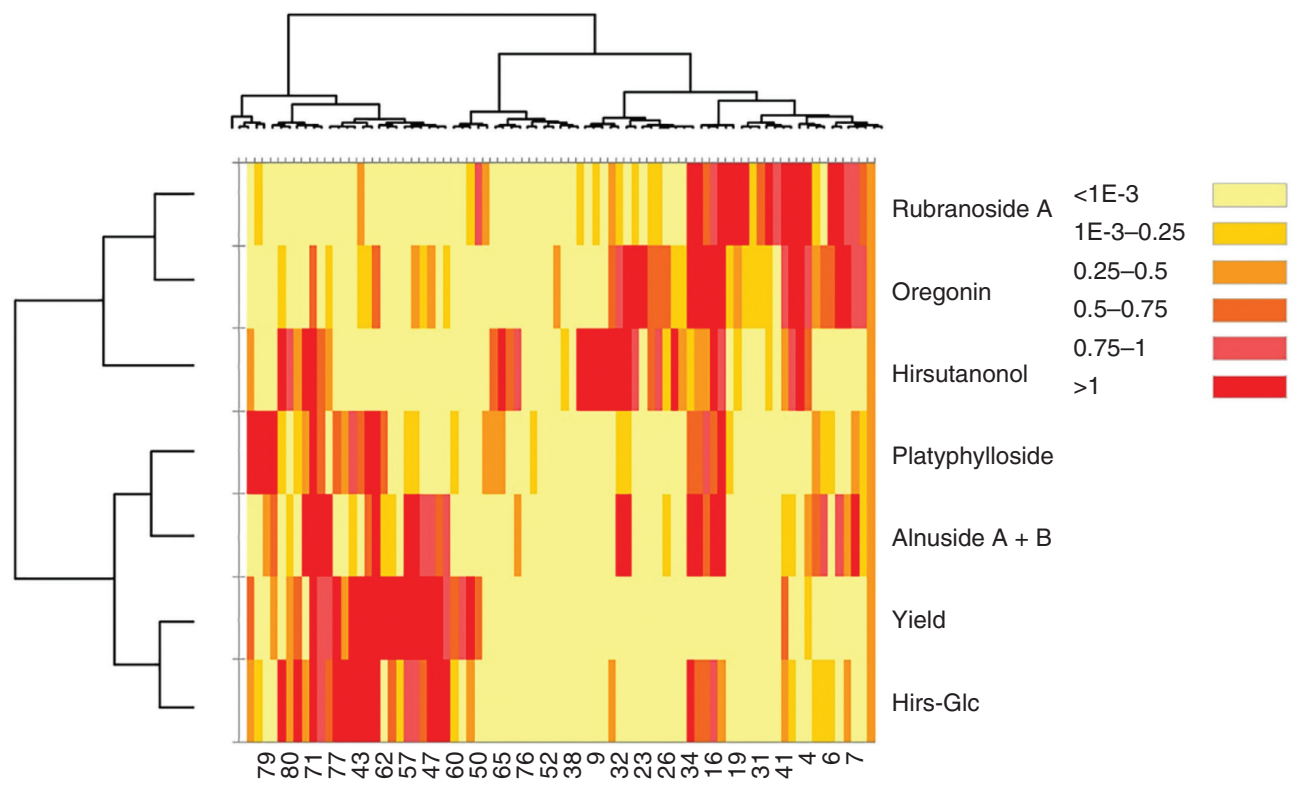

Figure 4: Heatmap - diarylheptanoid content of Alnus spp. individuals from the basic table transformed to shaded rectangular areas corresponding to the numerical classes.

The visual impression in the figure was made on the basis of the diarylheptanoid abundance in 80 individuals. Numbers in the axial legend denote individuals randomly selected by the software. It is technically impossible to display all the numbers without them overlapping each other.

and molecular weights of the diarylheptanoid compounds used as standards are presented in Figure 3. In the present study, research was extended to two additional populations that served as a control in order to achieve a greater insight into inter- and intraspecies' chemovariability. The first impression of diarylheptanoid abundance was made by examining the toned rectangular areas in the heatmap
(Figure 4) that correspond to the numerical classes of the transformed values from the basic table of elements and variables (data not shown). Alnuside A and B, being structural isomers, gave the same precursor and product ions for MRM, which could not be separated by UPLC. Thus, their sum was the input in further analyses. Alnus glutinosa individuals (upper right area on the map) possess
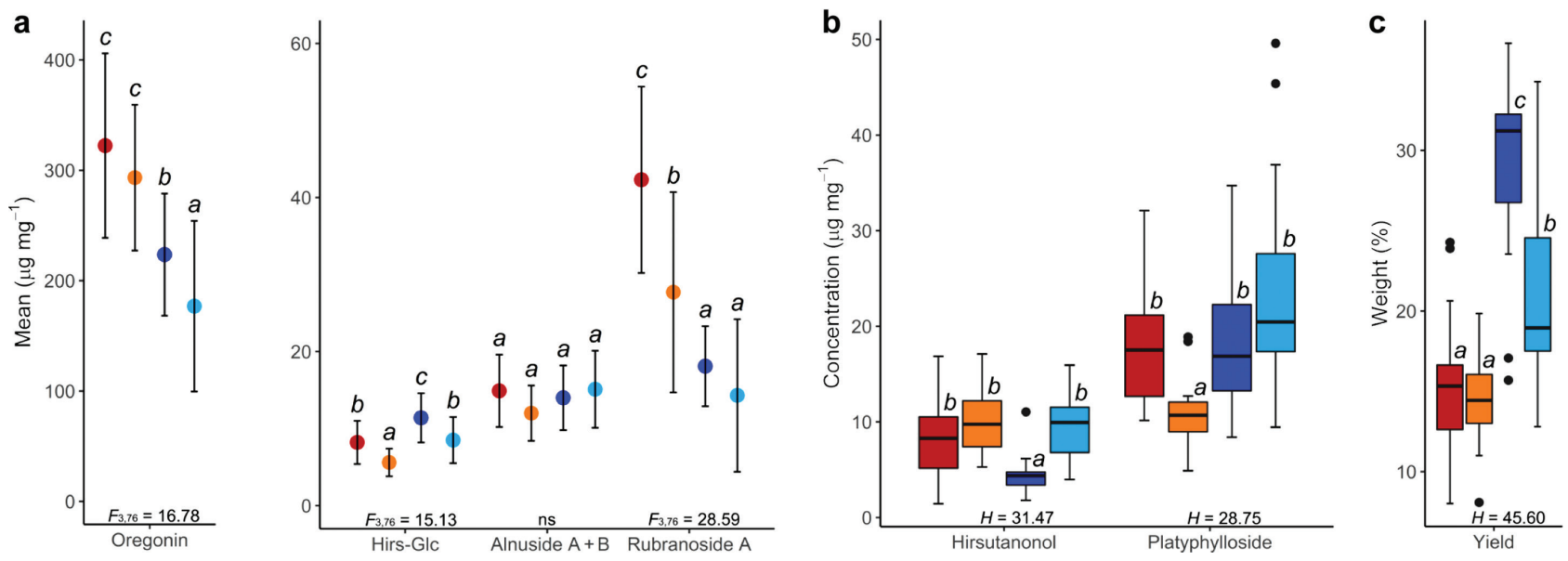

Figure 5: Comparisons of four populations: A. glutinosa (I, red), A. glutinosa (II, orange), A. incana (III, dark blue) and A. incana (IV, light blue) based on: (a) mean values of concentrations of each diarylheptanoid compound ( $\mu \mathrm{g} \mathrm{mg}^{-1}$ of ethanol extract), (b) median values of concentrations of each diarylheptanoid compound ( $\mu \mathrm{g} \mathrm{mg}^{-1}$ of ethanol extract) and (c) median values of bark ethanol extract yields (\% w/w). $F=F$ value (ANOVA) with degrees of freedom. Significant differences among the means were determined by Fisher's least significant difference post hoc test; mean value (colored circle) with standard deviation; $H=H$ value (Kruskal-Wallis test). To determine significant differences among the medians, we visually examined features of box-and-whisker plots of median notch; median value (bar) with interquartile range (colored rectangle), min-max value and outliers. ns, non-significant difference between the means or medians $(\mathrm{P}>0.05)$. Letters $(a, b, c)$ denote statistically significant differences $(\mathrm{P}<0.05)$ among populations. 
higher concentrations of rubranoside A and oregonin, and $A$. incana individuals (lower left area) are richer in hirsutanonol-5-O- $\beta$-D-glucopyranoside content and have higher extract yields.

The main statistical parameters concerning compounds and their extract yields are presented in Figure 5. Statistically significant differences are more pronounced between "pure" populations (I and III) than between "close" populations (II and IV). Populations I and III show no difference in the concentration of platyphylloside, while populations II and IV do not differ in hirsutanonol content.

\section{Chemovariability of the distant locus classicus populations of $A$. glutinosa and}

\section{A. incana}

PCA performed on the data from populations I and III resulted in the first two principal components ( $\mathrm{PC} 1$ and PC2) explaining 38.8 and $32.3 \%$ of the initial information, respectively (Figure 6). Based on the sum of squared correlations between the variables and factors in the plane of PC1 and PC2, oregonin and hirsutanonol-5-O- $\beta$ D-glucopyranoside are the most reliable characteristics (sum of $\mathrm{r}^{2}$ higher than 0.9 and 0.7, respectively). Oregonin had the highest impact in the formation of PC1 and hirsutanonol-5-O- $\beta$-D-glucopyranoside in the formation of PC2. The structure of the variables and their relations are visualized in Figure 6a and the tendencies between the individuals and their clustering, in Figure $6 \mathrm{~b}$. Based on the sum of squared cosines of points in the principal plane of the first two axes, individuals 10, 12, 18, 51 and 55 are poorly represented (sum of $\cos ^{2}<0.5$ ). The general impression is that populations I and III are clearly separated. The only evident similarity is in the content of platyphylloside, while other components are contrasted between the populations. Individuals in population III are characterized by higher extract yields and content of hirsutanonol5-O- $\beta$-D-glucopyranoside, and lower concentrations of hirsutanonol, rubranoside A and oregonin, compared to individuals from population I (Figures 5 and 6).

\section{Chemovariability of closely located populations of $A$. glutinosa and $A$. incana}

PCA was carried out on the data from populations II and IV, and the results show that PC1 accounted for 37.6\% of the initial information and PC2, for 24.9\% (Figure 7). Extract yield and oregonin are the most reliable characteristics in the plane of PC1 and PC2 (sum of $\mathrm{r}^{2}>0.8$ ), while alnuside $\mathrm{A}$ and $\mathrm{B}$ and platyphylloside are well represented $\left(0.6<\right.$ sum of $\left.r^{2}<0.8\right)$, i.e. these variables are the most important contributors to the the total variability. Extract yield, alnuside A and B and platyphylloside had the most influence on the formation of PC1, and oregonin had the most impact on PC2. The structure of characteristics and their relations can be seen in Figure 7a, while clustering of individuals is visible in Figure 7b. Fifteen individuals are a

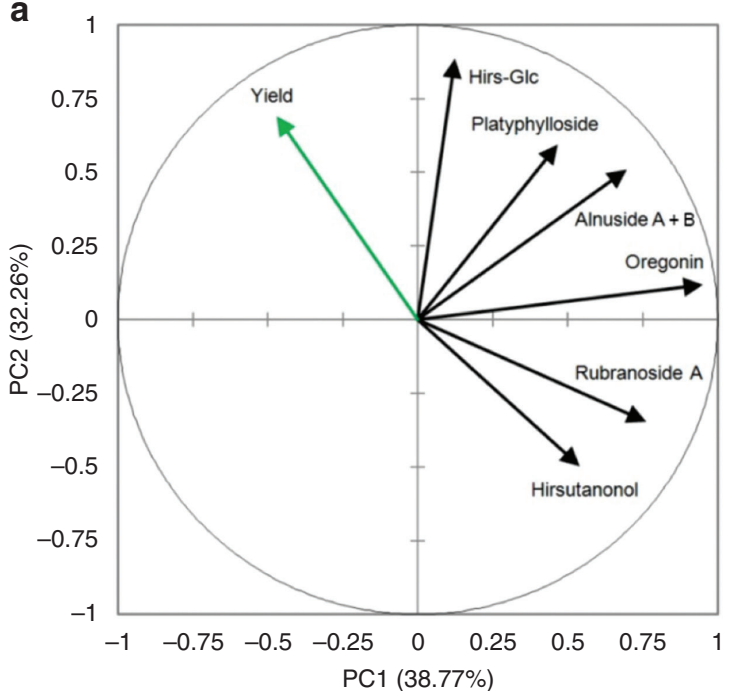

b

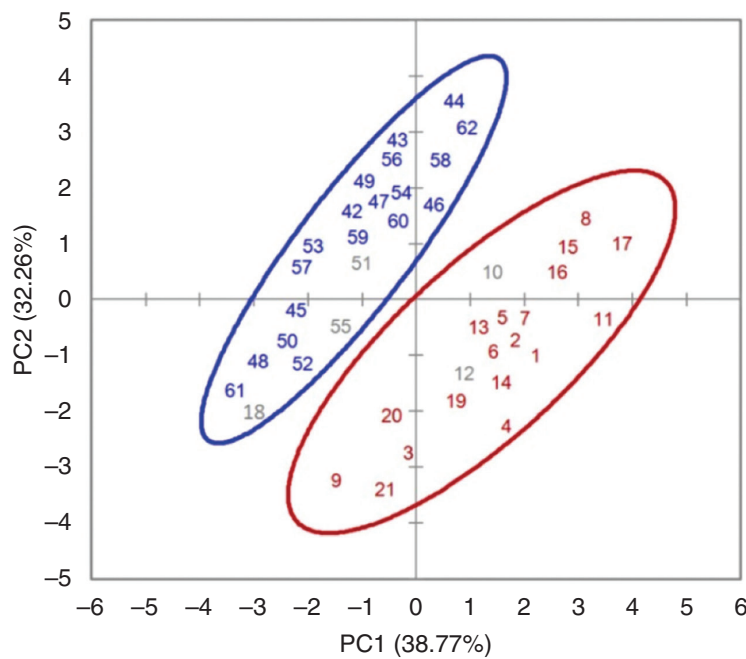

Figure 6: PCA of seven variables measured from individuals in populations I and III.

(a) Loading plot. Structure of characteristics/variables in the plane of the first two axes in individuals of locus classicus populations of A. glutinosa (I) and A. incana (III). (b) Score plot. Separation of individuals and populations I and III according to the contents of seven variables in the plane of the first two axes (individuals labeled 1-21=I; 42-62=III). The ellipses describe approximate $95 \%$ confidence regions. 


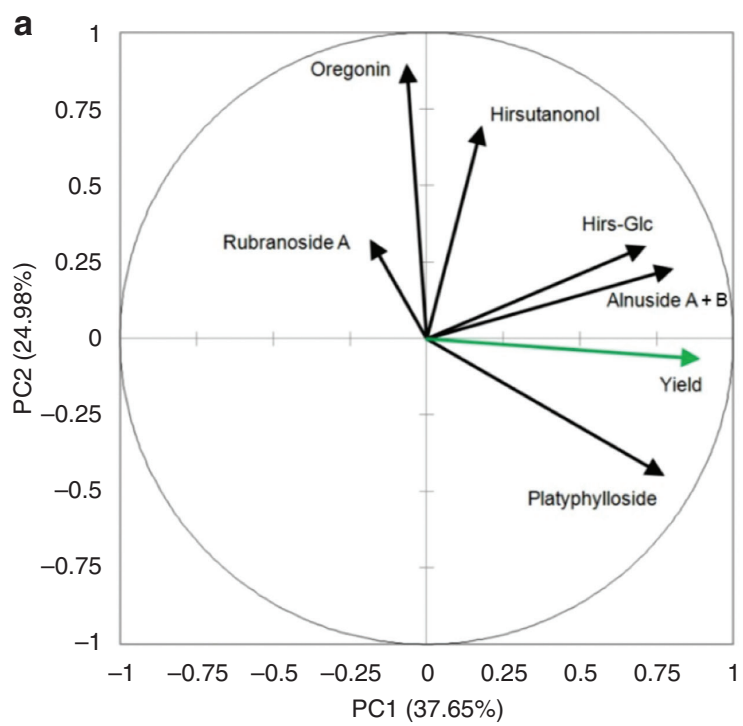

b

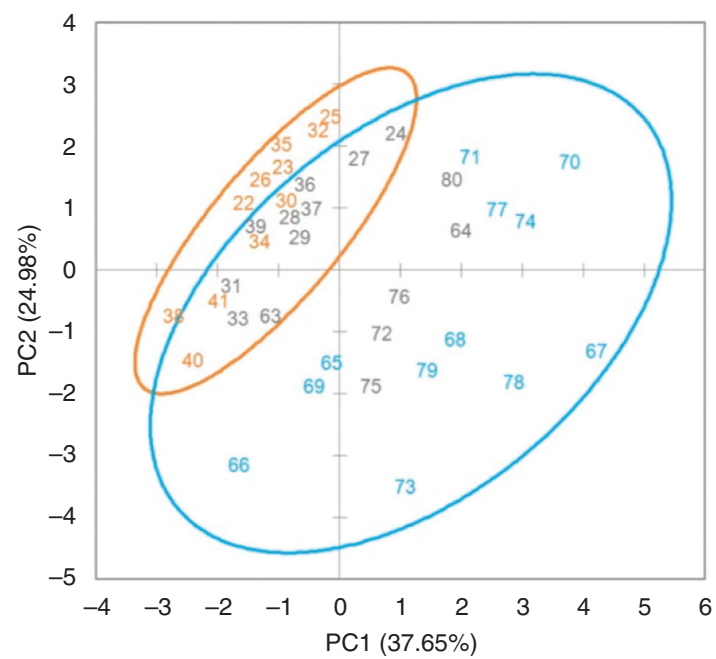

Figure 7: PCA of seven variables measured from individuals in populations II and IV.

(a) Loading plot. Structure of characteristics/variables in the plane of the first two axes in individuals of the geographically close populations of $A$. glutinosa (II) and $A$. incana (IV). (b) Score plot. Separation of individuals and populations II and IV according to the contents of seven variables in the plane of the first two axes (individuals labeled $22-41=I 1 ; 63-80=I V$ ). The ellipses describe approximate $95 \%$ confidence regions.

poorly represented in this plane: $24,27,28,29,31,33,36$, 37, 39, 63, 64, 72, 75, 76 and 80 (sum of $\cos ^{2}<0.5$ ). Populations II and IV are more similar to each other than are the "pure" populations I and III. Population II individuals have higher concentrations of rubranoside $\mathrm{A}$ and lower platyphylloside content and extract yields when compared to individuals from population IV; individuals from both populations show similar concentrations of hirsutanonol (Figures 5 and 7).

\section{Inter- and intraspecific chemovariability of A. glutinos $a$ and $A$. incana}

PCA was performed on all four populations of $A$. glutinosa and $A$. incana (Figure 8), where two distant populations of black and gray alder (I and III) served as representatives of "pure" populations. The results confirmed the conclusion from our previous study (Vidaković et al. 2018) that the interspecific differences in diarylheptanoid concentrations are suitable for species identification. PCA resulted in a three-component model that explained $76.6 \%$ of the total data variance. The most reliable characteristics in the plane of PC1 and PC2 are hirsutanonol-5-O- $\beta$-D-glucopyranoside, alnuside A and $\mathrm{B}$, yield, platyphylloside and oregonin $(0.40<$ sum of $\mathrm{r}^{2}<0.80$ ). Hirsutanonol-5- $O-\beta$-D-glucopyranoside and oregonin had the greatest influence on the formation of PC1 and PC2, respectively. The structure and relations of characteristics are given in Figure 8a. The clustering of individuals is easily seen in the plane of the first two PCs (Figure 8b). Individuals 5, 10, 12, 18, 24, 64, 65, 71, 76,77 and 80 are poorly represented in this plane (sum of $\cos ^{2}<0.5$ ). All populations display conspicuous intrapopulation variability. Although populations are heterogeneous based on the individuals' characteristics and partially overlap, intraspecific differences are noticeable: individuals from populations I and II (A. glutinosa) show differences in concentrations of hirsutanonol5-O- $\beta$-D-glucopyranoside, platyphylloside and rubranoside $\mathrm{A}$ and individuals from populations III and IV (A. incana) differ in their contents of hirsutanonol-5-O- $\beta$ D-glucopyranoside, oregonin, hirsutanonol and extract yield (Figure 5). The most diversified is population IV. It seems that the geographical proximity of populations II and IV increases their chemical similarity.

DA was employed for the discrimination of $a$ priori defined groups and for assorting the elements inside the groups (Figure 9). Both the discriminant functions were statistically significant (chi-square test, $\mathrm{P}<0.01$ ). The first discriminant function explained more than $88 \%$ of the discrimination and it mainly distinguished population III from the other groups by higher values for hirsutanonol5-O- $\beta$-D-glucopyranoside and yield (Figures 5 and 9). The second discriminant function mostly separated population IV from other populations by lower oregonin and higher hirsutanonol values. In total, 67 of 80 data (84\%) were correctly classified. 


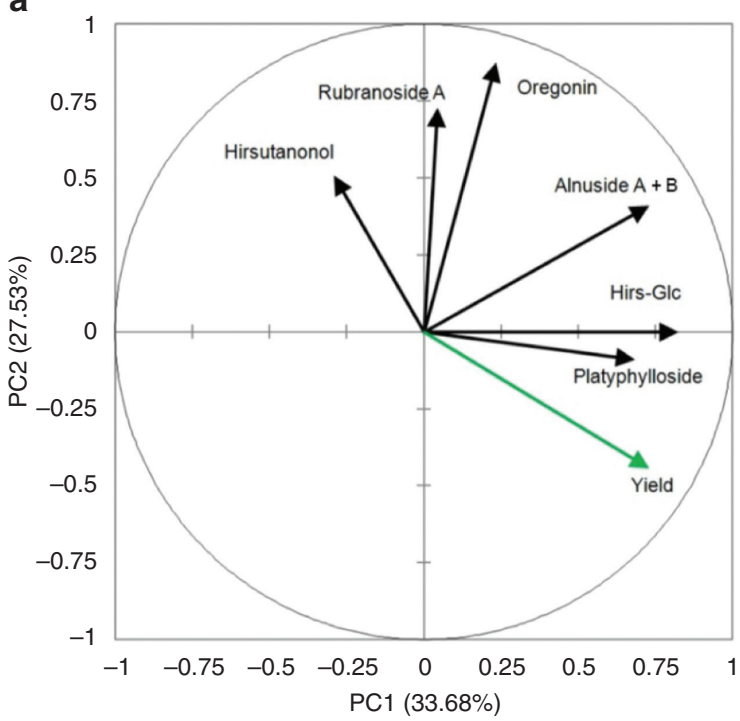

b

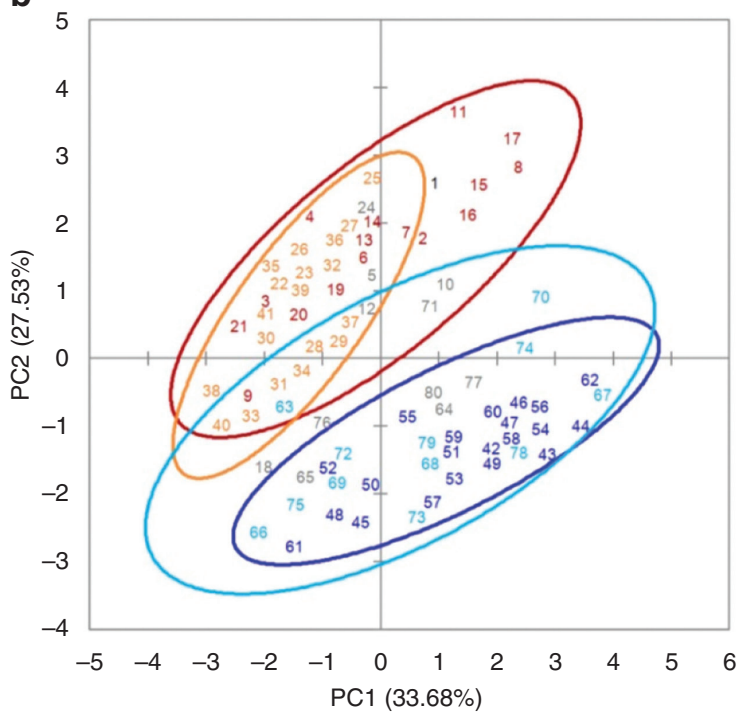

Figure 8: PCA of seven variables measured in individuals from populations I, II, III and IV.

(a) Loading plot. Structure of the characteristics/variables in the plane of the first two axes in individuals from populations I, II, III and IV. (b) Score plot. Separation of individuals and populations I, II, III and IV according to the contents of seven variables in the plane of the first two axes (individuals labeled according to Figures 6 and 7). The ellipses describe approximate $95 \%$ confidence regions.

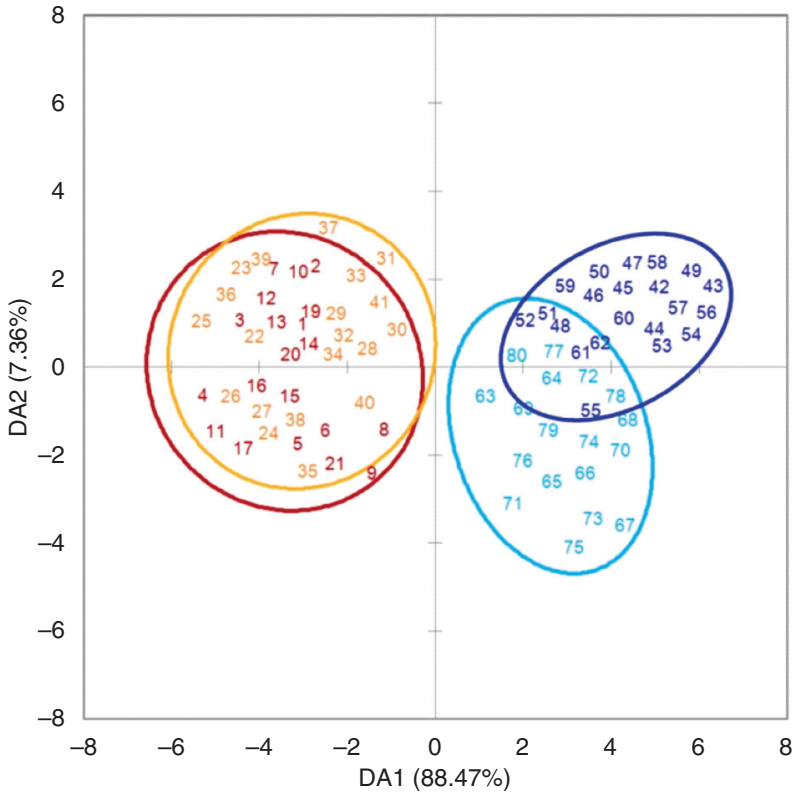

Figure 9: DA of four populations of Alnus spp. Positions of the analyzed individuals and populations within the first and second discriminant axes. The ellipses describe approximate $95 \%$ confidence regions.

The variability of diarylheptanoids is highly pronounced within populations (Figure 8). Overlapping with all the other groups, population IV (A. incana) displayed the highest dispersion of individuals. One of the reasons for this may be the appearance of hybrids in this population located at a small distance $(1.2 \mathrm{~km})$ from population II
(A. glutinosa). Changes in plant phenotype due to hybridization can affect specific biotic and abiotic interactions and can have broader community effects (Gange 1995; Whitham et al. 1999; Caseys et al. 2015). In general, approximately $70 \%$ of the chemical traits present in both parents are also expressed in hybrids (Orians 2000). The quantity of the metabolites may be intermediate between the parents, or closer to one of them. Besides, with lower frequency, hybrids synthesize compounds that are underor overexpressed, or completely new compounds. Hybrid individuals are expected in the overlapping area of confidence ellipses that line out populations II and IV (Figures 7 and 8), but they may also be represented by single individuals isolated from a group. In a study of black alder populations in Poland, Mejnartowicz (2008) found that genetic diversity was higher within populations than among them and that the spatial genetic structure of populations was formed in connection with the hydrological system of the area. A similar scenario is possible in the present study of populations belonging to the same river system of the Moravica (Figure 1). Equivalent results, i.e. more pronounced genetic variation within populations, have been obtained for gray alder (Huenneke 1985; Bousquet et al. 1988). Such a pattern of genetic variability can be seen among woody species with a large geographic distribution, long-distance pollen and seed dispersal and outcrossing breeding systems, because this set of characteristics facilitates gene flow (Loveless and Hamrick 1984; Prat et al. 1992). 


\section{Inter- and intraspecific variability of A. glutinosa and $A$. incana leaf shapes}

The Procrustes fit of the 1458 leaf configurations separated the shape variation into a symmetric component, which explained $80.8 \%$, and an asymmetric component, which explained $19.2 \%$ of the total. The main trends of shape variation are represented by the principal components of the symmetric covariance matrix. The first three PCs explained $89.8 \%$ of the total symmetric variation. On the plot of the first and second PCs (Figure 10a), A. glutinosa specimens are distributed mainly in the negative, and specimens of $A$. incana are distributed in the positive segment of PC1. A continuum of leaf shapes can be observed along PC1: between obovate shapes with a long petiole, narrow-cuneate base and rounded and emarginated apex at the extreme negative end, and ovate shapes with a short petiole, wide-cuneate base and acuminate apex at the extreme positive end. Between these extremes, a transition of shapes and partial overlapping of Alnus species can be detected. These results are in accordance with earlier reports on morphological delimitation of the species and their hybrids (Parnell 1994; Banaev and Bažant 2007; Vander Mijnsbrugge 2015). As in the PCA of chemical traits (Figure $8 \mathrm{~b}$ ), the search for hybrid individuals in the overlapping zone of the species is important (Figure 10a). Nevertheless, leaves that belong to individuals from the control populations I and III also appear in the overlapping area, indicating a high natural variability of leaf shapes within species and the need for more detailed morphometric and molecular genetic studies.
The PCA of the asymmetry covariance matrix did not show differentiation of species and population in terms of asymmetry (Figure 10b). A separate Procrustes fit of individual populations shows that the asymmetric component varied from $23.0 \%$ (population I) to $28.8 \%$ (population IV) of the total variation.

Analysis of chemical traits and of leaf shapes revealed that the main trends of variation were toward species differentiation, which confirmed the chemotaxonomic power of the selected diarylheptanoids. In addition, diarylheptanoids displayed solid intraspecific differentiation. The intraspecific variability of leaf shapes needs to be further investigated.

\section{Conclusions}

The most abundant alder diarylheptanoids were quantified in bark extracts in order to differentiate between locus classicus A. glutinosa, locus classicus A. incana and two geographically close populations of these species in the potential hybridization zone. The results presented here broaden the knowledge of the chemovariability and taxonomy of these complex species, confirming previous findings in terms of diarylheptanoids as good markers at inter- and intraspecific levels. Their potential for hybrid detection needs to be corroborated by genetic and more detailed morphometric studies. Preliminary morphometric analysis revealed transient leaf shapes between species, which supports the hypothesis of hybrid appearance. The results of this research performed on trees grown
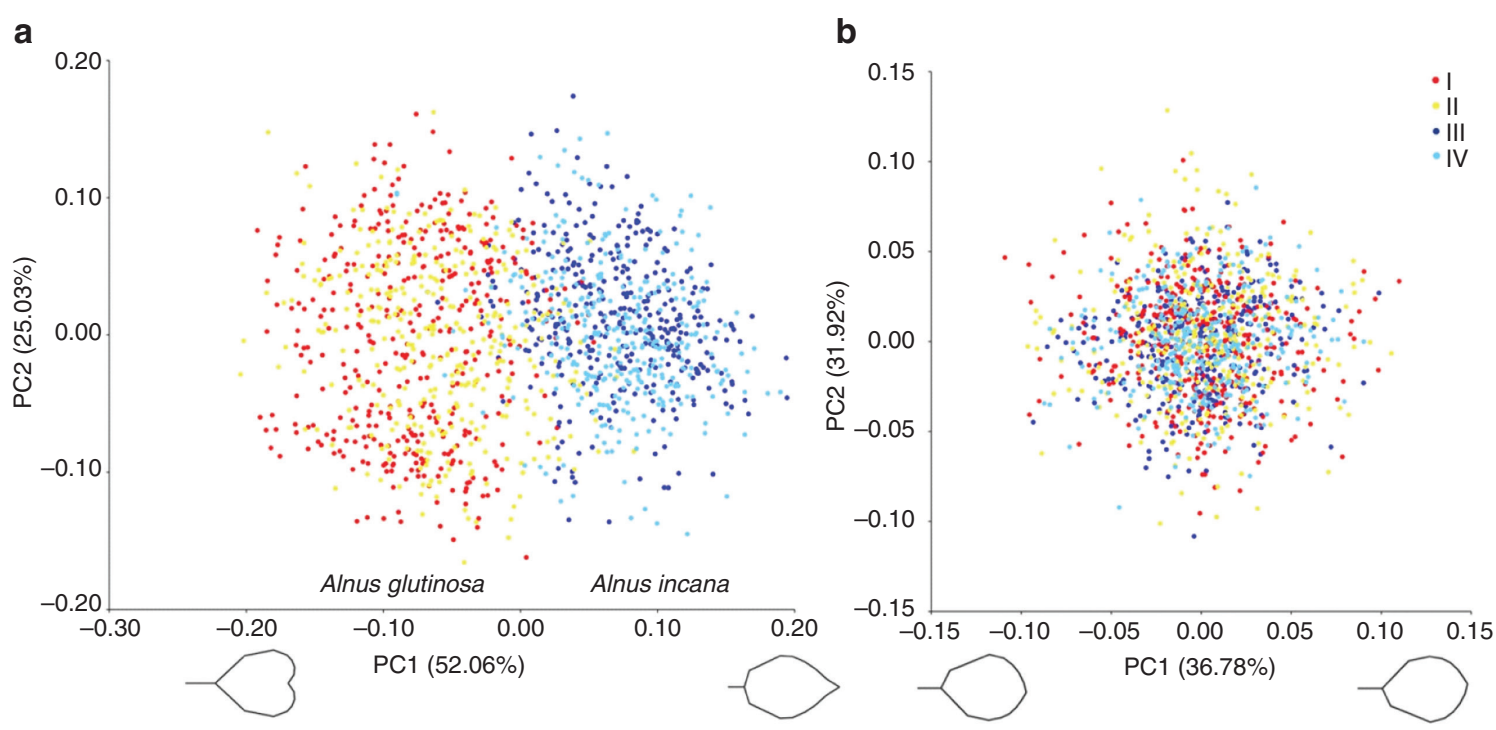

Figure 10: Positioning of individuals and populations I, II, III and IV according to the leaf shape in the plane of the first two PC axes. PCA of symmetric (a) and asymmetric (b) covariance matrices of 1458 Procrustes-aligned leaf configurations. 
in an exceptional natural and cultural heritage (GolijaStudenica Biosphere Reserve, UNESCO-MAB) provide a firm scientific basis for the conservation of biodiversity.

Acknowledgments: This research was supported financially by the Serbian Ministry of Education, Science and Technological Development, Project Nos. 173011 and 172053. We are grateful to Mrs. Myra MacphersonPoznanović for the professional native-English editing of the manuscript.

Author contributions: All the authors have accepted responsibility for the entire content of this submitted manuscript and approved submission.

Research funding: None declared.

Employment or leadership: None declared.

Honorarium: None declared.

\section{References}

Akbarian, M.R., Tabari, M., Akbarinia, M., Zarafshar, M., Meave, J.A., Yousefzadeh, H., Sattarian, A. (2011) Effects of elevational gradient on leaf and stomatal morphology of Caucasian alder (Alnus subcordata) in the Hyrcanian forest, Iran. Folia Oecologica 38:203-224.

Anderson, A.B., Riffer, R., Wong, A. (1970) Chemistry of Genus Pinus. VII. Monoterpenes, Fatty and Resin Acids of Pinus monophylla and Pinus quadrifolia. Holzforschung 24:182-184.

Banaev, E.V. (2009) On the effect of climate on the morphological structure of Alnus hirsuta (Betulaceae). Russ. J. Ecol. 40:18-23.

Banaev, E.V., Bažant, V. (2007) Study of natural hybridization between Alnus incana (L.) Moench. and Alnus glutinosa (L.) Gaertn. J. For. Sci. 53:66-73.

Banjanac, T., Dragićević, M., Šiler, B., Gašić, U., Bohanec, B., Nestorović Živković, J., Trifunović, S., Mišić, D. (2017) Chemodiversity of two closely related tetraploid Centaurium species and their hexaploid hybrid: metabolomic search for high-resolution taxonomic classifiers. Phytochemistry 140:27-44.

Bašić, N., Selimović, E., Pustahija, F. (2014) Morphological identification of nothospecies Alnus $\times$ Pubescens Tausch. and their new localities in central Bosnia. Works Fac. For. Univ. Sarajevo 44:15-24.

Bousquet, J., Cheliak, W.M., Lalonde, M. (1988) Allozyme variation within and among mature populations of speckled alder (Alnus rugosa) and relationships with green alder (A. crispa). Am. J. Bot. 75:1678-1686.

Caseys, C., Stritt, C., Glauser, G., Blanchard, T., Lexer, C. (2015) Effects of hybridization and evolutionary constraints on secondary metabolites: the genetic architecture of phenylpropanoids in European populus species. PLoS One 10:e0128200.

Claessens, H., Oosterbaan, A., Savill, P., Rondeux, J. (2010) A review of the characteristics of black alder (Alnus glutinosa (L.) Gaertn.) and their implications for silvicultural practices. For. Int. J. For. Res. 83:163-175.
Dinić, J., Novaković, M., Podolski-Renić, A., Stojković, S., Mandić, B., Tešević, V., Vajs, V., Isaković, A., Pešić, M. (2014) Antioxidative activity of diarylheptanoids from the bark of black alder (Alnus glutinosa) and their interaction with anticancer drugs. Planta Med. 80:1088-1096.

Gajić, M. Flora and vegetation of the golija and javor. Šumarski fakultet, Beograd, OOUR Šumarstvo “Golija”, Ivanjica, 1989.

Gange, A.C. (1995) Aphid performance in an alder (Alnus) hybrid zone. Ecology 76:2074-2083.

Hamrick, J.L., Godt, M.J.W., Sherman-Broyles, S.L. (1992) Factors influencing levels of genetic diversity in woody plant species. New For. 6:95-124.

Huang, X., Tang, G., Liao, Y., Zhuang, X., Dong, X., Liu, H., Huang, X.-J., Ye, W.-C., Wang, Y., Shi, L. (2016) 7-(4-Hydroxyphenyl)-1phenyl-4E-hepten-3-one, a diarylheptanoid from Alpinia officinarum, protects neurons against amyloid- $\beta$ induced toxicity. Biol. Pharm. Bull. 39:1961-1967.

Huenneke, L.F. (1985) Spatial distribution of genetic individuals in thickets of Alnus incana ssp. rugosa, a clonal shrub. Am. J. Bot. 72:152-158.

Jovanović, B. Dendrologija. Šumarski fakultet, Beograd, 2007.

Kalaw, J.M., Sevilla III, F.B. (2018) Discrimination of wood species based on a carbon nanotube/polymer composite chemiresistor array. Holzforschung 72:215-223.

Klingenberg, C.P. (2011) MorphoJ: an integrated software package for geometric morphometrics. Mol. Ecol. Resour. 11:353-357.

Krauze-Michalska, E., Boratyńska, K. (2013) European geography of Alnus incana leaf variation. Plant Biosyst. 147:601-610.

Loveless, M.D., Hamrick, J.L. (1984) Ecological determinants of genetic structure in plant populations. Annu. Rev. Ecol. Syst. 15:65-95.

Mejnartowicz, L. (2008) Genetic variation within and among naturally regenerating populations of alder (Alnus glutinosa). Acta Soc. Bot. Pol. 77:105-110.

Mikola, P., Uomala, P., Mälkönen, E. (1983) Application of biological nitrogen fixation in European silviculture. In: Biological Nitrogen Fixation in Forest Ecosystems: Foundations and Applications. Eds. Gordon, J.C., Wheeler, C.T. Springer Dordrecht, Netherlands. pp. 279-294.

Moore, B.D., Andrew, R.L., Külheim, C., Foley, W.J. (2014) Explaining intraspecific diversity in plant secondary metabolites in an ecological context. New Phytol. 201:733-750.

Nawawi, D.S., Syafii, W., Akiyama, T., Matsumoto, Y. (2016) Characteristics of guaiacyl-syringyl lignin in reaction wood in the gymnosperm Gnetum gnemon L. Holzforschung 70:593-602.

Nicotra, A.B., Leigh, A., Boyce, C.K., Jones, C.S., Niklas, K.J., Royer, D.L., Tsukaya, H. (2011) The evolution and functional significance of leaf shape in the angiosperms. Funct. Plant Biol. 38:535-552.

Novaković, M., Stanković, M., Vučković, I., Todorović, N., Trifunović, S., Tešević, V., Vajs, V., Milosavljević, S. (2013) Diarylheptanoids from Alnus glutinosa bark and their chemoprotective effect on human lymphocytes DNA. Planta Med. 79:499-505.

Novaković, M., Pešić, M., Trifunović, S., Vučković, I., Todorović, N., Podolski-Renić, A., Dinić, J., Stojković, S., Tešević, V., Vajs, V., Milosavljević, S. (2014) Diarylheptanoids from the bark of black alder inhibit the growth of sensitive and multi-drug resistant non-small cell lung carcinoma cells. Phytochemistry 97:46-54. 
Novaković, M., Novaković, I., Cvetković, M., Sladić, D., Tešević, V. (2015) Antimicrobial activity of the diarylheptanoids from the black and green alder. Braz. J. Bot. 38:441-446.

Orians, C.M. (2000) The effects of hybridization in plants on secondary chemistry: implications for the ecology and evolution of plant-herbivore interactions. Am. J. Bot. 87:1749-1756.

Orians, C.M., Griffiths, M.E., Roche, B.M., Fritz, R.S. (2000) Phenolic glycosides and condensed tannins in Salix sericea, S. eriocephala and their F1 hybrids: not all hybrids are created equal. Biochem. Syst. Ecol. 28:619-632.

Parnell, J.A.N. (1994) Variation and hybridisation of Alnus Miller in Ireland. Watsonia 20:67-70.

Poethig, R.S. (1990) Phase change and the regulation of shoot morphogenesis in plants. Science 250:923-930.

Prat, D., Leger, C., Bojović, S. (1992) Genetic diversity among Alnus glutinosa (L.) Gaertn. population. Acta Oecologica 13:469-477.

Rohlf, J. (2016a) tpsUtil v 1.70 (computer program). Stony Brook University, New York.

Rohlf, J. (2016b) tpsDig2. v 2.26 (computer program). Stony Brook University, New York.

Šarac, Z., Bojović, S., Nikolić, B., Tešević, V., Đorđević, I., Marin, P.D. (2013) Chemotaxonomic significance of the terpene composition in natural populations of Pinus nigra J.F. Arnold from Serbia. Chem. Biodiversity 10:1507-1520.

Sartori, C., da Silva Mota, G., Ferreira, J., Miranda, I., Mori, F.A., Pereira, H. (2016) Chemical characterization of the bark of Eucalyptus urophylla hybrids in view of their valorization in biorefineries. Holzforschung 70:819-828.

Saxena, A., Yadav, D., Maurya, A.K., Kumar, A., Mohanty, S., Gupta, M.M., Lingaraju, M.C., Yatoo, M.I., Thakur, U.S., Bawankule, D.U. (2016) Diarylheptanoids from Alnus nepalensis attenuates LPS-induced inflammation in macrophages and endotoxic shock in mice. Int. Immunopharmacol. 30:129-136.

Sueth-Santiago, V., Moraes, J.B., Sobral Alves, E.S., Vannier-Santos, M.A., Freire-de-Lima, C.G., Castro, R.N., Mendes-Silva, G.P., Del Cistia, C.N., Magalhães, L.G., Andricopulo, A.D., Sant'Anna, C.M.R., Decoté-Ricardo, D., Freire de Lima, M.E. (2016) The effectiveness of natural diarylheptanoids against Trypanosoma cruzi: cytotoxicity, ultrastructural alterations and molecular modeling studies. PLoS One 11:e0162926.
Suksen, K., Charaslertrangsi, T., Noonin, C., Jariyawat, S., Devakul Na Ayutthaya, W., Suksamrarn, A., Tuchinda, P., Piyachaturawat, P. (2016) Protective effect of diarylheptanoids from Curcuma comosa on primary rat hepatocytes against $t$-butyl hydroperoxide-induced toxicity. Pharm. Biol. 54:853-862.

Thongon, N., Boonmuen, N., Suksen, K., Wichit, P., Chairoungdua, A., Tuchinda, P., Suksamrarn, A., Winuthayanon, W., Piyachaturawat, P. (2017) Selective estrogen receptor modulator (SERM)-like activities of diarylheptanoid, a phytoestrogen from Curcuma comosa, in breast cancer cells, pre-osteoblast cells, and rat uterine tissues. J. Agric. Food Chem. 65:3490-3496.

van Rozendaal, E.L.M., Kurstjens, S.J.L., van Beek, T.A., van den Berg, R.G. (1999) Chemotaxonomy of Taxus. Phytochemistry 52:427-433.

Vander Mijnsbrugge, K. (2015) Morphological dissection of leaf, bud and infructescence traits of the interfertile native $A$. glutinosa and non-native $A$. incana in Flanders (northern part of Belgium). Trees 29:1661-1672.

Vidaković, V., Novaković, M., Popović, Z., Janković, M., Matić, R., Tešević, V., Bojović, S. (2018) Significance of diarylheptanoids for chemotaxonomical distinguishing between Alnus glutinosa and Alnus incana. Holzforschung 72:9-16.

Wang, S.N., Zhang, F.D., Huang, A.M., Zhou, Q. (2016) Distinction of four Dalbergia species by FTIR, 2nd derivative IR, and 2D-IR spectroscopy of their ethanol-benzene extractives. Holzforschung 70:503-510.

Whitham, T.G., Martinsen, G.D., Keim, P., Floate, K.D., Dungey, H.S., Potts, B.M., Keim, P. (1999) Plant hybrid zones affect biodiversity: tools for a genetic-based understanding of community structure. Ecology 80:416-428.

Wu, C.-C., Chu, F.-H., Ho, C.-K., Sung, C.-H., Chang, S.-H. (2017) Comparative analysis of the complete chloroplast genomic sequence and chemical components of Cinnamomum micranthum and Cinnamomum kanehirae. Holzforschung 71:189-197.

Yu, M., Liu, K., Zhou, L., Zhao, L., Liu, S. (2016) Testing three proposed DNA barcodes for the wood identification of Dalbergia odorifera T. Chen and Dalbergia tonkinensis Prain. Holzforschung 70:127-136.

Zelditch, M.L., Swiderski, D.L., Sheets, H.D. Geometric morphometrics for biologists: a primer. Elsevier, Amsterdam, 2012. 